\title{
Article
}

\section{The Oxygen-Generating Calcium Peroxide-Modified Magnetic Nanoparticles Attenuate Hypoxia-Induced Chemoresistance in Triple-Negative Breast Cancer}

\author{
Fong-Yu Cheng ${ }^{1,+}+\mathbb{D}$, Chia-Hsin Chan ${ }^{2,+}+\mathbb{D}$, Bour-Jr Wang ${ }^{3,4}$, Ya-Ling Yeh ${ }^{5}$, Ying-Jan Wang $5,6,7, *(\mathbb{D}$ \\ and Hui-Wen Chiu $7,8,9,10, *$ (D)
}

check for updates

Citation: Cheng, F.-Y.; Chan, C.-H.; Wang, B.-J.; Yeh, Y.-L.; Wang, Y.-J.; Chiu, H.-W. The Oxygen-Generating Calcium Peroxide-Modified Magnetic Nanoparticles Attenuate Hypoxia-Induced Chemoresistance in Triple-Negative Breast Cancer. Cancers 2021, 13, 606. https://doi. org/10.3390/cancers13040606

Academic Editors: Georgios Giamas and Teresa Gagliano

Received: 23 December 2020

Accepted: 27 January 2021

Published: 3 February 2021

Publisher's Note: MDPI stays neutral with regard to jurisdictional claims in published maps and institutional affiliations.

Copyright: (C) 2021 by the authors Licensee MDPI, Basel, Switzerland. This article is an open access article distributed under the terms and conditions of the Creative Commons Attribution (CC BY) license (https:// creativecommons.org/licenses/by/ $4.0 /)$.
1 Department of Chemistry, Chinese Culture University, Taipei 11114, Taiwan; zfy3@ulive.pccu.edu.tw

2 Department of Pharmacological Sciences, Stony Brook University, Stony Brook, NY 11790, USA; chia-hsin.chan@stonybrook.edu

3 Department of Occupational and Environmental Medicine, National Cheng Kung University Hospital, Tainan 70101, Taiwan; smalladou@mail.cnu.edu.tw

4 Department of Cosmetic Science and Institute of Cosmetic Science, Chia Nan University of Pharmacy and Science, Tainan 71710, Taiwan

5 Department of Environmental and Occupational Health, College of Medicine, National Cheng Kung University, Tainan 70101, Taiwan; linn7627@mail.ncku.edu.tw

6 Department of Medical Research, China Medical University Hospital, China Medical University, Taichung 40402, Taiwan

7 Graduate Institute of Clinical Medicine, College of Medicine, Taipei Medical University, Taipei 11031, Taiwan

8 Division of Nephrology, Department of Internal Medicine, Shuang Ho Hospital, Taipei Medical University, New Taipei City 23561, Taiwan

9 TMU Research Center of Urology and Kidney, Taipei Medical University, Taipei 11031, Taiwan

10 Department of Medical Research, Shuang Ho Hospital, Taipei Medical University, New Taipei City 23561, Taiwan

* Correspondence: yjwang@mail.ncku.edu.tw (Y.-J.W.); leu3@tmu.edu.tw (H.-W.C.); Tel.: +886-6-2353535 (Y.-J.W.); +886-2-22490088 (H.-W.C.)

+ These authors contributed equally to this work.

Simple Summary: Tumor hypoxia is known to increase the resistance of cancer cells to chemotherapy. Triple-negative breast cancer (TNBC) is the most aggressive subtype of breast cancer and lack of target. Therefore, chemotherapy is the only approved systemic treatment in TNBC. Here, we synthesized the calcium peroxide-modified magnetic nanoparticles $\left(\mathrm{CaO}_{2}-\mathrm{MNPs}\right)$ with the function of oxygen generation to improve and enhance the therapeutic efficiency of doxorubicin treatment in the hypoxia microenvironment of TNBC. $\mathrm{CaO}_{2}-\mathrm{MNPs}$ promoted ubiquitination and protein degradation of hypoxia-inducible factor $1 \alpha(\mathrm{HIF}-1 \alpha)$. Furthermore, $\mathrm{CaO}_{2}-\mathrm{MNPs}$ inhibited autophagy and induced apoptosis in TNBC cells. $\mathrm{CaO}_{2}$-MNPs in combination with doxorubicin showed a stronger tumorsuppressive effect on TNBC compared to the doxorubicin treatment alone in an orthotopic mouse model. Our findings suggest that combined with $\mathrm{CaO}_{2}-\mathrm{MNPs}$ and doxorubicin attenuates HIF- $1 \alpha$ expression to improve the efficiency of chemotherapy in TNBC.

Abstract: Cancer response to chemotherapy is regulated not only by intrinsic sensitivity of cancer cells but also by tumor microenvironment. Tumor hypoxia, a condition of low oxygen level in solid tumors, is known to increase the resistance of cancer cells to chemotherapy. Triple-negative breast cancer (TNBC) is the most aggressive subtype of breast cancer. Due to lack of target in TNBC, chemotherapy is the only approved systemic treatment. We evaluated the effect of hypoxia on chemotherapy resistance in TNBC in a series of in vitro and in vivo experiments. Furthermore, we synthesized the calcium peroxide-modified magnetic nanoparticles $\left(\mathrm{CaO}_{2}-\mathrm{MNPs}\right)$ with the function of oxygen generation to improve and enhance the therapeutic efficiency of doxorubicin treatment in the hypoxia microenvironment of TNBC. The results of gene set enrichment analysis (GSEA) software showed that the hypoxia and autophagy gene sets are significantly enriched in TNBC patients. We found that the chemical hypoxia stabilized the expression of hypoxia-inducible factor $1 \alpha(\mathrm{HIF}-1 \alpha)$ protein and increased doxorubicin resistance in TNBC cells. Moreover, hypoxia inhibited the induction 
of apoptosis and autophagy by doxorubicin. In addition, $\mathrm{CaO}_{2}-\mathrm{MNPs}$ promoted ubiquitination and protein degradation of HIF- $1 \alpha$. Furthermore, $\mathrm{CaO}_{2}-\mathrm{MNPs}$ inhibited autophagy and induced apoptosis in TNBC cells. Our animal studies with an orthotopic mouse model showed that $\mathrm{CaO}_{2}{ }^{-}$ MNPs in combination with doxorubicin exhibited a stronger tumor-suppressive effect on TNBC, compared to the doxorubicin treatment alone. Our findings suggest that combined with $\mathrm{CaO}_{2}-\mathrm{MNPs}$ and doxorubicin attenuates HIF-1 $\alpha$ expression to improve the efficiency of chemotherapy in TNBC.

Keywords: hypoxia; nanocarriers; chemoresistance; triple-negative breast cancer; autophagy

\section{Introduction}

Triple-negative breast cancer (TNBC) is a subtype of breast cancer defined by the absence of progesterone receptor, estrogen receptor and human epidermal growth factor receptor 2 [1,2]. TNBC accounts for up to $24 \%$ of all newly diagnosed breast cancers [3]. Lack of expression of these proteins makes TNBC an orphan disease when considering standard therapeutic regimens for breast cancer [4]. Current treatments of TNBC often includes surgery, radiotherapy and chemotherapy. Due to lack of target in TNBC, chemotherapy is the only approved systemic treatment [1]. However, cancer response to chemotherapy is regulated not only by intrinsic sensitivity of cancer cells but also by tumor microenvironment. Previous studies have demonstrated that tumor hypoxia, a condition of low oxygen level in solid tumors, increases the resistance of cancer cells to chemotherapy and radiotherapy $[5,6]$. Hypoxia affected breast cancer cell growth dynamics, angiogenesis, migration, endoplasmic reticulum (ER) stress and aggressive features $[7,8]$. About 50-60\% of advanced solid tumors, including breast cancer, comprise hypoxic region which is often related with poor survival [9-11]. Hypoxia-inducible factor $1 \alpha(\mathrm{HIF}-1 \alpha)$ is an essential regulator of molecular response to hypoxia. HIF- $1 \alpha$ is degraded in normoxic conditions. Furthermore, hypoxia increased HIF- $1 \alpha$ expression, which in turn changes many gene products that affect the regulation of metabolism, angiogenesis, cell cycle and apoptotic process [12]. Accumulating evidences have shown the involvement of hypoxia in the induction of chemo- and radio-resistance $[11,13,14]$. In addition, many reports have demonstrated that hypoxia increased chemoresistance in cancer cells through the activation of the HIF- $1 \alpha$ pathway $[15,16]$. These findings reveal that HIF- $1 \alpha$ plays a critical role in regulating tumor chemosensitivity. Recent evidence shows that parkin binds to HIF- $1 \alpha$ and causes HIF- $1 \alpha$ degradation by ubiquitination, which suppresses metastasis of breast cancer cells [17]. The HIF-1 $\alpha$ protein degradation in hypoxic conditions is ubiquitination-dependent [18].

Autophagy is a crucial homeostatic process in the human body that is responsible for the elimination of damaged proteins, lipids and organelles [19]. Autophagy is also a significant regulatory pathway during cancer cells against hypoxic stress. Therefore, autophagy is known to increase cancer cells survival and therapy resistance [20]. Cicchini et al. indicated that $B E C N 1$, which is an autophagy regulator, inhibited mammary tumorigenesis through WNT1 activation [21]. Previous studies have demonstrated that autophagy constrains sensitivity to cytotoxic therapy. Radiotherapy or chemotherapy induced autophagy is accompanied by therapy resistance in breast cancer cells [22]. Another recent study illustrated that hypoxia triggers cytoprotective autophagy and consequently attenuates sensitivity of TNBC cells to taxol treatment [23], suggesting that increasing oxygen tension may be an approach to increase chemotherapy sensitivity.

Nanotechnology has recently gained increased attention for cancer prevention, detection and treatment. Nanoparticles (NPs) have used to drug delivery, allowing for therapeutic drugs to selectively targeting tumor tissue, while reducing toxicity in normal cells [24]. Furthermore, nanocarriers are ideal platform for cancer therapies because they possess the properties of solubility enhancement effects, high drug loading capacity, controlled release and site-specific delivery mechanism [25]. Previous studies have reported using oxygen carrying microbubbles to reduce the tumor hypoxia and enhance 
sonodynamic therapeutic effect $[26,27]$. Li et al. showed that co-delivery of erlotinib and oxygen by liposomal complexes reverses hypoxia-induced drug resistance in lung cancer. Moreover, nanotherapeutics containing oxygen adjusts hypoxic microenvironment in tumor to improve therapeutic outcomes [28]. This study used calcium peroxide-modified magnetic nanoparticles $\left(\mathrm{CaO}_{2}-\mathrm{MNPs}\right)$ as an oxygen generation substrate because previous reports had indicated $\mathrm{CaO}_{2}$ has suitable oxygen release rate and good biocompatibility for bioapplications [29-31]. The study showed that oxygen is released from the $\mathrm{CaO}_{2}-\mathrm{MNPs}$ after mixture of $\mathrm{CaO}_{2}$-MNPs and water. In the present study, we examine the effect of doxorubicin which is a chemotherapeutic drug in hypoxic conditions in TNBC cells. Furthermore, we evaluate the anti-cancer effects of doxorubicin combined with $\mathrm{CaO}_{2}-\mathrm{MNPs}$ in TNBC cells in vitro and in an orthotopic mouse model. We present data showing that $\mathrm{CaO}_{2}-\mathrm{MNPs}$ treatment in TNBC reduces hypoxic stress in tumor evident by decreased HIF-1 $\alpha$ expression and increased doxorubicin-sensitivity in vivo.

\section{Results}

\subsection{Hypoxia Increases the Resistance of Cancer Cells to Chemotherapy in TNBC}

Firstly, the expression values of all of the genes in 17 normal tissues and primary tumors derived from 33 patients with TNBC were uploaded into gene set enrichment analysis (GSEA) software to analyze the enriched functions within the hypoxia gene set database (Figure 1A). The results identified that the hypoxia gene set was found to be significantly enriched in TNBC patients. Therefore, hypoxia plays an important role in TNBC. Next, we determine whether hypoxic condition increases the doxorubicin-resistance in TNBC cells. Cobalt chloride $\left(\mathrm{CoCl}_{2}\right)$ is a mimetic agent used in vitro to cause cellular hypoxia. $\mathrm{CoCl}_{2}$ stabilizes HIF-1 $\alpha$ by suppressing prolyl hydroxylase enzymes [32]. We analyzed the expression of HIF-1 $\alpha$ protein to confirm that the $\mathrm{CoCl}_{2}$ can effectively cause HIF-1 $\alpha$ protein stabilization in TNBC cells. As shown in Figure $2 \mathrm{~A}$, the treatment with $\mathrm{CoCl}_{2}$ increased the expression levels of HIF- $1 \alpha$ protein in a concentration-dependent manner in human breast cancer cells MDA-MB-231 and murine breast cancer cells 4T1. We next tested the impact of hypoxia on chemosensitivity. Pre-treatment with $\mathrm{CoCl}_{2}$ increased doxorubicin-resistance of MDA-MB-231 and 4T1 cells in a concentration-dependent manner of doxorubicin (Figure 2B). These results found that hypoxia can cause resistance of TNBC cells to doxorubicin.
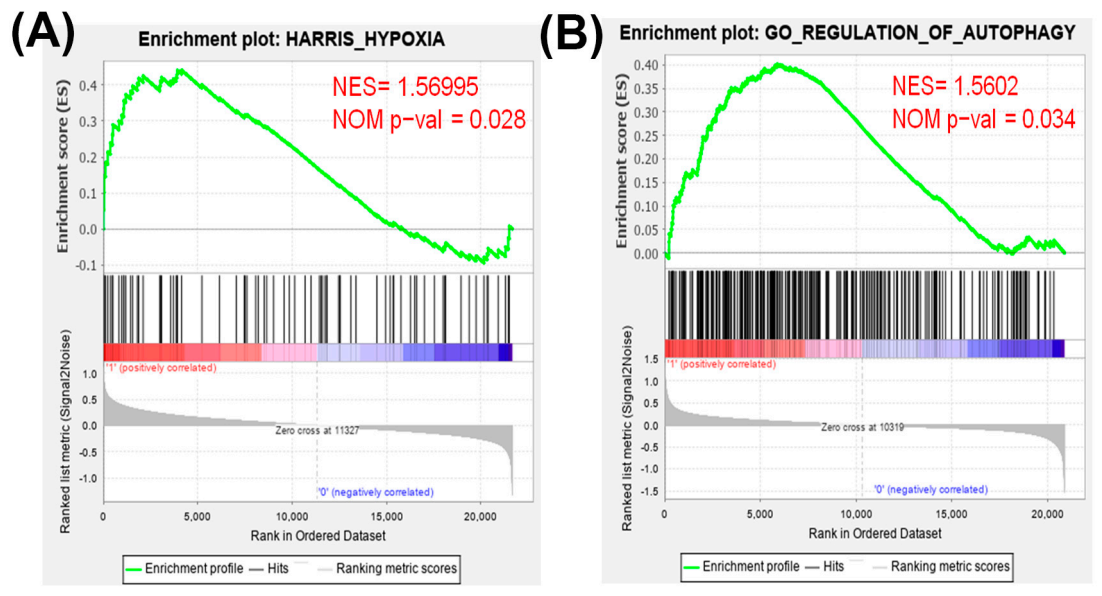

Figure 1. Gene set enrichment analysis (GSEA) of hypoxia and autophagy gene expressions in primary tumors and normal tissues derived from patients with triple-negative breast cancer (TNBC). All of the expressed genes were uploaded into GSEA for enrichment analysis. The Harris hypoxia (A) and Gene Ontology (GO) regulation of autophagy (B) gene sets database were used as the gene set collection for analysis. NES, normalized enrichment score; NOM p-val, nominal $p$ value. 

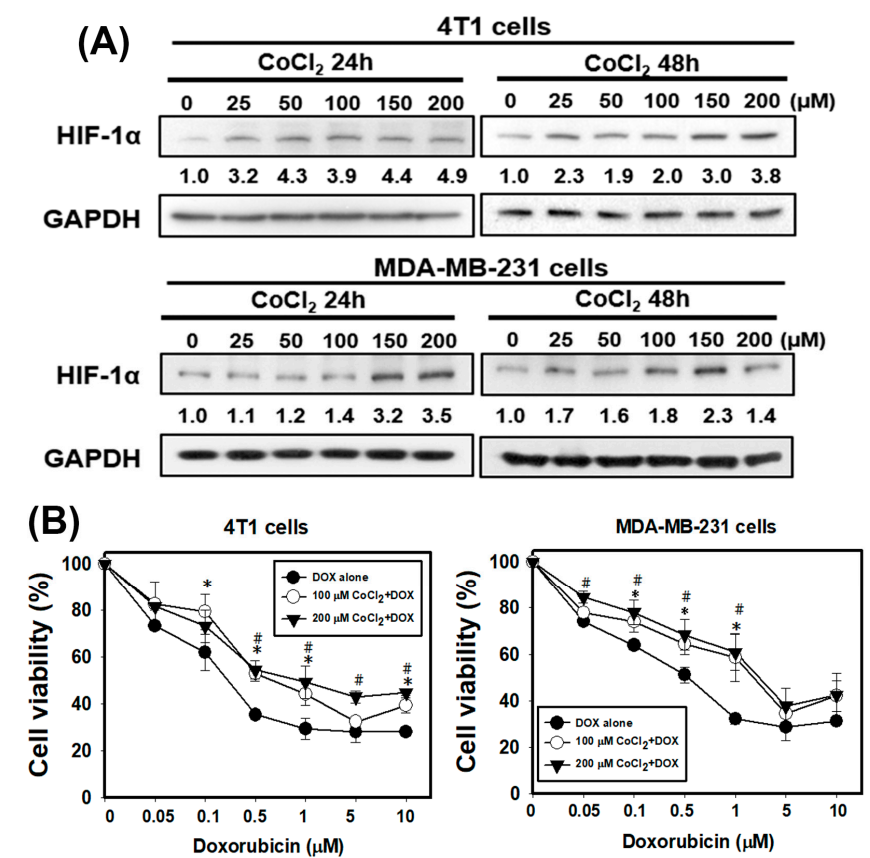

Figure 2. The chemical hypoxia $\left(\mathrm{CoCl}_{2}\right)$ stabilizes hypoxia-inducible factor $1 \alpha(\mathrm{HIF}-1 \alpha)$ protein and causes doxorubicin (DOX) resistance in TNBC cells. (A) the protein level of HIF-1 $\alpha$ in $4 \mathrm{~T} 1$ and MDA-MB-231 cells treated with $\mathrm{CoCl}_{2}$ for 24 and $48 \mathrm{~h}$. (B) effect of DOX on cell viability of $4 \mathrm{~T} 1$ and MDA-MB-231 cells in the absence or presence of $\mathrm{CoCl}_{2}$. Cells were pretreated with $\mathrm{CoCl}_{2}$ for $48 \mathrm{~h}$ and then treated with DOX for $24 \mathrm{~h} .{ }^{*} p<0.05$ DOX alone compared with $100 \mu \mathrm{M} \mathrm{CoCl}_{2}+\mathrm{DOX}$. $\# p<0.05$ DOX alone compared with $200 \mu \mathrm{M} \mathrm{CoCl}_{2}+\mathrm{DOX}$.

\subsection{Hypoxia Inhibits the Induction of Apoptosis and Increases Autophagy by Doxorubicin in TNBC}

Previous research has shown that hypoxia promoted radioresistance through suppressing radiation-induced apoptosis in cervical cancer cells [13]. In order to investigate whether hypoxia has a protective effect against apoptosis induced by doxorubicin in TNBC cells, 4T1 cells were treated in the presence or absence of doxorubicin under normoxia or hypoxia. Apoptosis in 4T1 cells was examined using flow cytometry with Annexin V (Figure 3A). The quantitative results indicated that doxorubicin induced approximately $60 \%$ of apoptosis. However, $200 \mu \mathrm{M} \mathrm{CoCl}_{2}$ protected $4 \mathrm{~T} 1$ cells from apoptotic cell death induced by doxorubicin. Next, we detected the apoptosis-related protein expression using Western blot analysis. The expression level of the anti-apoptotic protein (Bcl-XL) was inhibited, and pro-apoptotic protein (Bax) and cleaved-caspase 3 were increased with doxorubicin treatment (Figure 3B). $\mathrm{CoCl}_{2}$ enhanced the doxorubicin-inhibited $\mathrm{Bcl}-\mathrm{XL}$ and suppressed the doxorubicin-induced Bax and cleaved-caspase 3. All these data demonstrate that hypoxia can protect TNBC cells against the well-known apoptosis inducer, doxorubicin.

The gene expression in normal tissues and primary tumors derived from patients with TNBC were uploaded into GSEA software to evaluate the autophagy gene set database (Figure 1B). The data showed that the autophagy gene set was significantly enriched in TNBC patients. Previously the authors reported that doxorubicin triggered autophagy in breast cancer cells [33]. Moreover, autophagy increases cancer cells survival and therapy resistance [20]. To investigate whether $\mathrm{CoCl}_{2}$ can affect autophagy, we used the acridine orange (AO) stain which detected acidic vesicular organelles (AVOs) of autophagy feature [34]. We quantified AVOs in AO-stained cells by flow cytometry (Figure 3C). 4T1 cells treated with doxorubicin showed significantly increased AO-positive cells. Furthermore, cells pre-treated with $\mathrm{CoCl}_{2}$ induced higher percentage of autophagic cells than that of the doxorubicin alone, accompanied with upregulation of the autophagy-related proteins p62 and LC3-II (Figure 3C,D). 
(A)

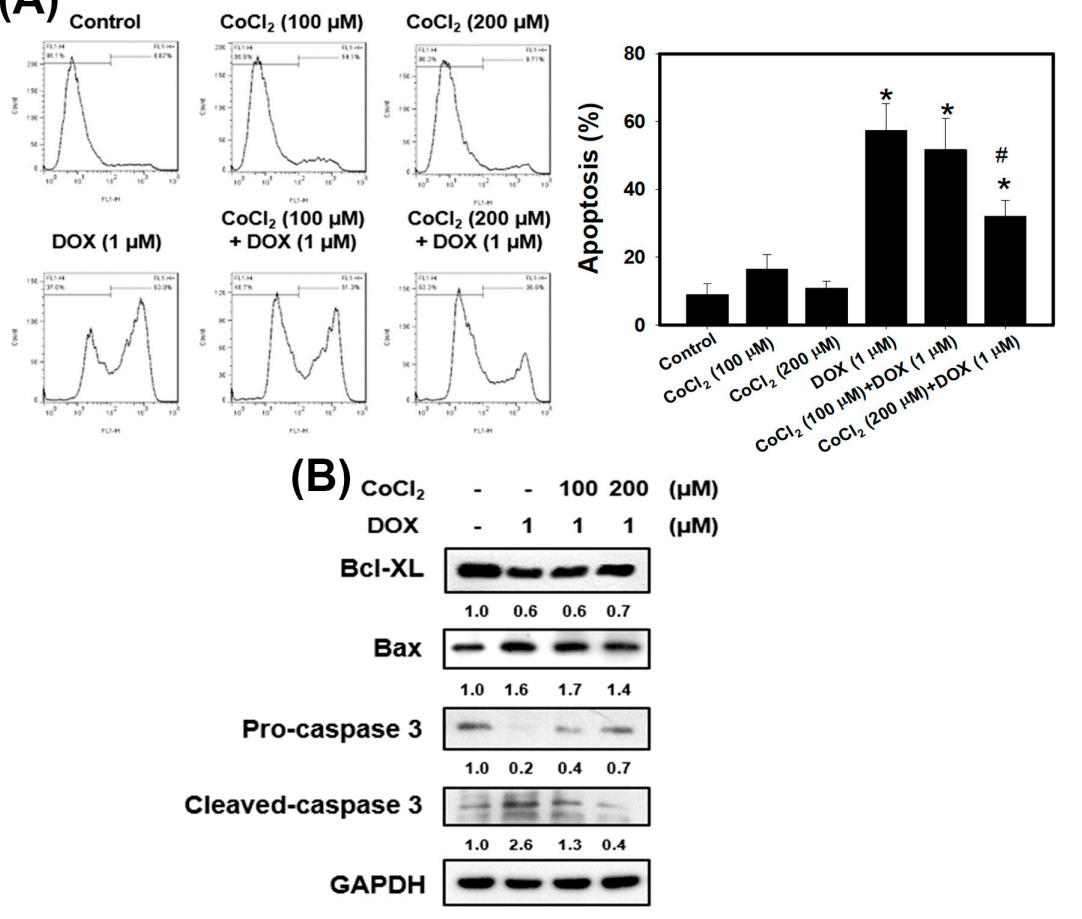

(C)
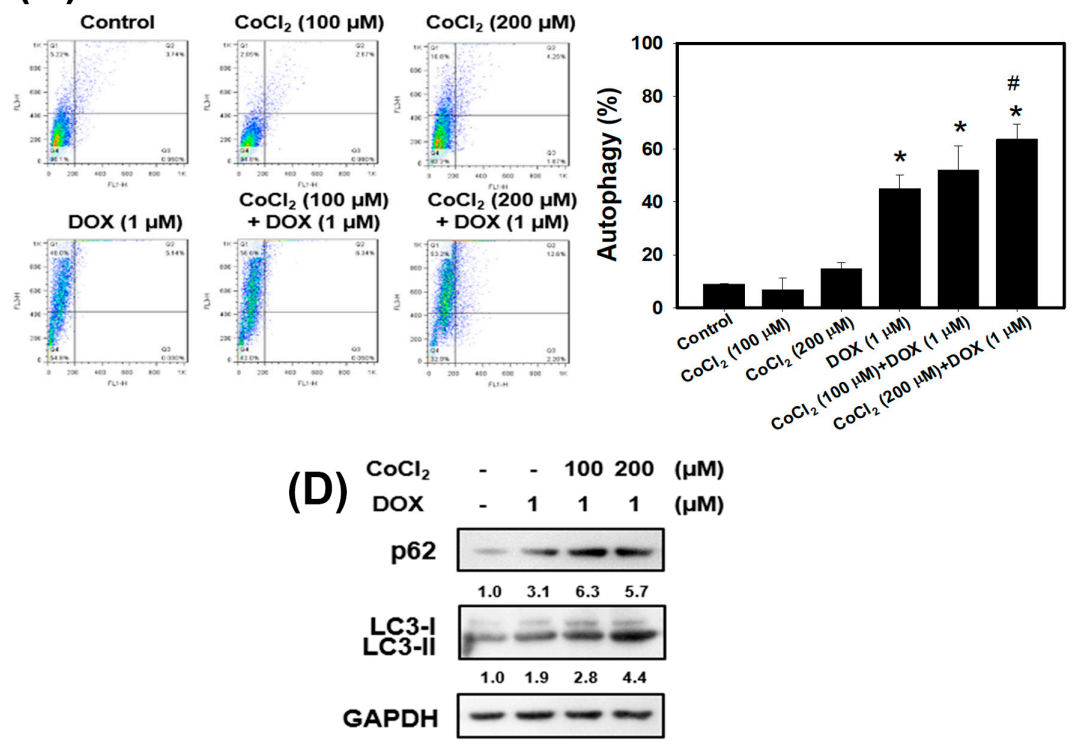

Figure 3. Detection of apoptosis and autophagy in $4 \mathrm{~T} 1$ cells that received DOX and/or $\mathrm{CoCl}_{2}$ treatments. (A) apoptosis was analyzed by flow cytometry with an Annexin $\mathrm{V}$ apoptosis detection kit. $4 \mathrm{~T} 1$ cells were pretreated with $\mathrm{CoCl}_{2}$ for $24 \mathrm{~h}$ and then treated with DOX for $24 \mathrm{~h} .{ }^{*} p<0.05$ compared with control. \# $p<0.05$ DOX alone compared with $200 \mu \mathrm{M} \mathrm{CoCl}_{2}+$ DOX. (B) effects of apoptosis-related protein expression in $4 \mathrm{~T} 1$ cells treated with $\mathrm{DOX}$ and $\mathrm{CoCl}_{2}$ alone or in combination. Cells were pretreated with $\mathrm{CoCl}_{2}$ for $24 \mathrm{~h}$ and then treated with DOX $(1 \mu \mathrm{M})$ for $24 \mathrm{~h}$. (C) measurement of acidic vesicular organelles (AVOs) in acridine orange (AO)-stained cells using flow cytometry. 4T1 cells were pretreated with $\mathrm{CoCl}_{2}$ for $24 \mathrm{~h}$ and then treated with DOX for $24 \mathrm{~h}$. ${ }^{*} p<0.05$ compared with control. \# $p<0.05$ DOX alone compared with $200 \mu \mathrm{M} \mathrm{CoCl}_{2}+$ DOX. (D) effects of autophagy-related protein expression in $4 \mathrm{~T} 1$ cells treated with $\mathrm{DOX}$ and $\mathrm{CoCl}_{2}$ alone or in combination. Cells were pretreated with $\mathrm{CoCl}_{2}$ for $24 \mathrm{~h}$ and then treated with DOX $(1 \mu \mathrm{M})$ for $24 \mathrm{~h}$. 


\subsection{Chemical and Physical Characteristics of $\mathrm{CaO}_{2}-\mathrm{MNPS}$}

The $\mathrm{CaO}_{2}-\mathrm{MNPs}$ were successfully prepared from amine group-modified MNPs $\left(\mathrm{NH}_{2}-\mathrm{MNPs}\right)$ via two states of $\mathrm{COOH}-$ modified MNPs (COOH-MNPs) and $\mathrm{Ca}^{2+} / \mathrm{COOH}-$ MNPs. TEM images of COOH-MNPs and $\mathrm{CaO}_{2}-\mathrm{MNPs}$ are shown in Figure $4 \mathrm{~A}$ and their real diameters of $\mathrm{COOH}-\mathrm{MNPs}$ and $\mathrm{CaO}_{2}-\mathrm{MNPs}$ are calculated about $7.1 \mathrm{~nm}$ and $7.3 \mathrm{~nm}$. The hydrodynamic diameters of $\mathrm{COOH}-\mathrm{MNPs}$ and $\mathrm{CaO}_{2}-\mathrm{MNPs}$ are $32.5 \mathrm{~nm}$ and $45.1 \mathrm{~nm}$ measured by dynamic light scattering (DLS) instrument (Figure S1A). The surface charges of $\mathrm{COOH}-\mathrm{MNPs}$ and $\mathrm{CaO}_{2}$-MNPs are $-30.6 \mathrm{mV}$ and $-9.3 \mathrm{mV}$ (Figure S1B). Dissolved oxygen (DO) release profile of $\mathrm{CaO}_{2}$-MNPs in the close system was monitored over time (Figure 4B). The elevating DO levels of $\mathrm{CaO}_{2}-\mathrm{MNPs}$ was near to $3.5 \mathrm{mg} / \mathrm{L}$, whereas the $\mathrm{Ca}^{2+} / \mathrm{COOH}-\mathrm{MNPs}$ (precursor of $\mathrm{CaO}_{2}-\mathrm{MNPs}$ ) had no oxygen production in water. Optical photographs showed that bubbles (oxygen) were produced after $\mathrm{CaO}_{2}-$ MNPs mixed with water for $10 \mathrm{~min}$ (Figure 4C), but no bubbles could be observed in $\mathrm{Ca}^{2+} / \mathrm{COOH}-\mathrm{MNPs}$ mixed with water at the same time interval. Furthermore, the $\mathrm{pH}$ value varieties of $\mathrm{CaO}_{2}$-MNPs in PBS buffer ( $\mathrm{pH}$ 7.4) and deionized water were measured by $\mathrm{pH}$ meter (Figure $4 \mathrm{D}$ ). The slightly increased and no changed $\mathrm{pH}$ values were separately observed when $\mathrm{CaO}_{2}-\mathrm{MNPs}$ incubated with deionized water and PBS buffer. No changes of $\mathrm{pH}$ values were also found when $\mathrm{Ca}^{2+} / \mathrm{COOH}-\mathrm{MNPs}$ mixed with water.

(A)

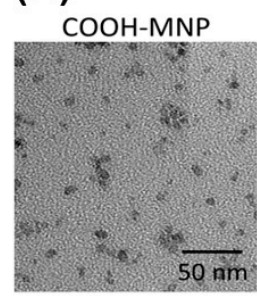

(C)

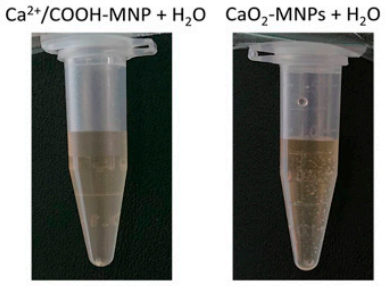

(B)

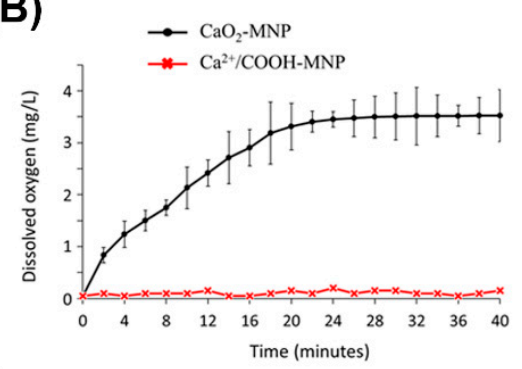

(D)

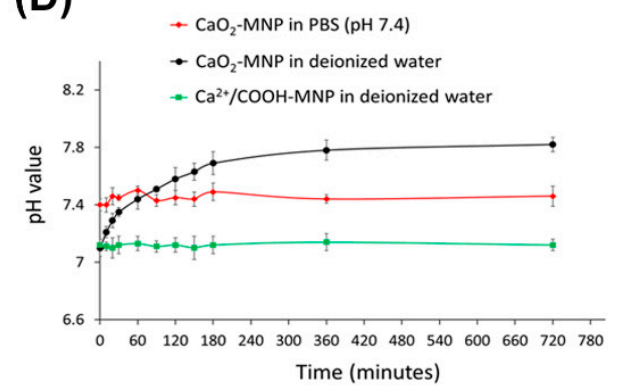

Figure 4. Chemical and physical characteristics of calcium peroxide-modified magnetic nanoparticles $\left(\mathrm{CaO}_{2}\right.$-MNPs). (A) TEM images of $\mathrm{COOH}$-modified MNPs (COOH-MNPs) and $\mathrm{CaO}_{2}-\mathrm{MNPs}$. The used solvents for preparing TEM samples of $\mathrm{COOH}-\mathrm{MNPs}$ and $\mathrm{CaO}_{2}-\mathrm{MNPs}$ were water and polyethylene glycol (M.W. 200) (PEG200), respectively. (B) dissolved oxygen kinetics after the addition of $\mathrm{Ca}^{2+} / \mathrm{COOH}-\mathrm{MNPs}$ or $\mathrm{CaO}_{2}$-MNPs $(0.1 \mathrm{~mL}$; Fe concentration: $0.9 \mathrm{mg} / \mathrm{mL})$ into $20 \mathrm{~mL}$ of water at room temperature. (C) optical photographs of $\mathrm{Ca}^{2+} / \mathrm{COOH}-\mathrm{MNPs}$ and $\mathrm{CaO}_{2}-\mathrm{MNPs}$ incubated with water. (D) the $\mathrm{pH}$ value profiles after addition of $\mathrm{Ca}^{2+} / \mathrm{COOH}-\mathrm{MNPs}$ and $\mathrm{CaO}_{2}$-MNPs ( $0.1 \mathrm{~mL}$; Fe concentration: $0.9 \mathrm{mg} / \mathrm{mL}$ ) in $20 \mathrm{~mL}$ of PBS buffer ( $\mathrm{pH}$ 7.4) or water at room temperature.

\section{4. $\mathrm{CaO}_{2}-\mathrm{MNPs}$ Promote Ubiquitination and Protein Degradation of HIF-1 $\alpha$, and Increases TNBC Sensitivity to Doxorubicin in Hypoxic Conditions}

We found that $\mathrm{CaO}_{2}$-modified MNPs can inhibit the $\mathrm{CoCl}_{2}$-stabilized HIF- $1 \alpha$ in a concentration-dependent manner in 4T1 cells (Figure 5A). It is well known that rapid degradation of specific proteins by ubiquitin-proteasome system (UPS) is a component of many cellular mechanisms [35]. We speculated that $\mathrm{CaO}_{2}-\mathrm{MNPs}$ cause HIF- $1 \alpha$ degradation through ubiquitination. To study this possibility, we investigated the HIF-1 $\alpha$ ubiqui- 
tination by immunoprecipitation (IP). We observed that $\mathrm{CaO}_{2}-\mathrm{MNPs}$ induced HIF-1 $\alpha$ ubiquitination (Figure 5B). Therefore, $\mathrm{CaO}_{2}-\mathrm{MNPs}$-triggered the HIF-1 $\alpha$ degradation may be regulated by UPS. Next, we found that pre-treatment with $\mathrm{CoCl} 2$ markedly increased doxorubicin-resistance in $4 \mathrm{~T} 1$ cells (Figure 5C). However, $\mathrm{CaO}_{2}-\mathrm{MNPs}$ inhibited the $\mathrm{CoCl}_{2}-$ induced doxorubicin-resistance. We further investigated the effect of autophagy and apoptosis by $\mathrm{CaO}_{2}-\mathrm{MNPs}$. $\mathrm{CoCl}_{2}$ increased the doxorubicin-induced autophagy while $\mathrm{CaO}_{2}-\mathrm{MNPs}$ significantly suppressed that effect (Figure 5D). Additionally, $\mathrm{CaO}_{2}-\mathrm{MNPs}$ reverted doxorubicin-induced apoptosis under $\mathrm{CoCl}_{2}$ treatment (Figure 5E).

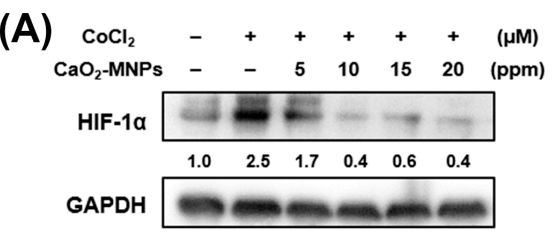

(B)

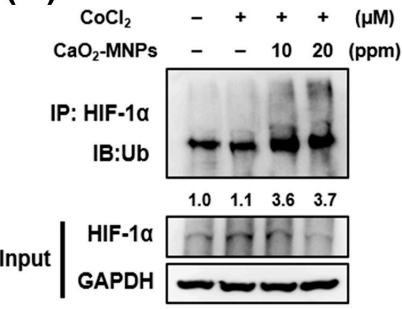

(D)



(C)

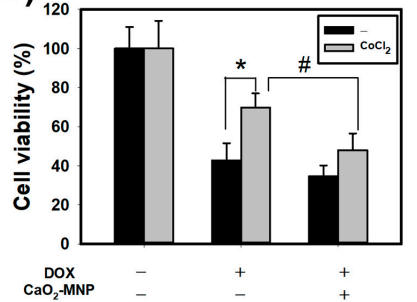

(E)

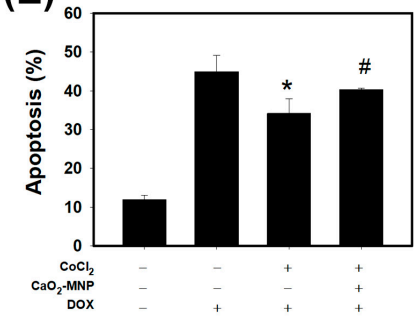

Figure 5. $\mathrm{CaO}_{2}$-modified MNPs cause protein degradation and ubiquitination of hypoxia-inducible factor $1 \alpha(\mathrm{HIF}-1 \alpha)$, and reverts the effects of DOX on apoptosis and autophagy in 4T1 cells. (A) Western blot analysis for HIF-1 $\alpha$ protein expression. Cells were incubated with $\mathrm{CoCl}_{2}(100 \mu \mathrm{M})$ for $24 \mathrm{~h}$, treated with $\mathrm{CaO}_{2}-\mathrm{MNPs}$ for $24 \mathrm{~h}$, then harvested for protein extraction and then subjected to western blot analysis. (B) immunoprecipitation (IP) assay for HIF-1 $\alpha$ ubiquitination. 4 T1 cells incubated with $\mathrm{CoCl}_{2}(100 \mu \mathrm{M})$ for $24 \mathrm{~h}$ and treated with $\mathrm{CaO}_{2}-\mathrm{MNPs}$ for $24 \mathrm{~h}$. The total protein lysates harvested from $4 \mathrm{~T} 1$ cells were immunoprecipitated with anti-HIF- $1 \alpha$ antibody. The complexes and the input were examined using western blot analysis with anti-ubiquitin antibody. Effect of $\mathrm{CaO}_{2}-\mathrm{MNPs}_{\mathrm{N}}$ on cell viability (C), autophagy (D) and apoptosis (E) of $4 \mathrm{~T} 1$ cells. Cells were pretreated with $\mathrm{CoCl}_{2}$ $(100 \mu \mathrm{M})$ for $8 \mathrm{~h}$, treated with $\mathrm{CaO}_{2}$-MNPs $(20 \mathrm{ppm})$ for $16 \mathrm{~h}$, then incubated with DOX $(1 \mu \mathrm{M})$ for 24 h. ${ }^{*} p<0.05 \mathrm{DOX}$ alone compared with DOX $+\mathrm{CoCl}_{2}$. \# $p<0.05 \mathrm{DOX}+\mathrm{CoCl}_{2}$ compared with $\mathrm{DOX}+\mathrm{CoCl}_{2}+\mathrm{CaO}_{2}$-MNPs.

\subsection{The Anti-Cancer Effects of Doxorubicin in Combination with CaO2-MNPs in an Orthotopic Mouse Model}

4T1 cells were stably transfected with luciferase (4T1-Luc) and 4T1-Luc cells were used in the orthotopic breast cancer of mouse model. 4T1-Luc cells were inoculated into the mammary fat pads of Balb/c mice. Mice were observed for 4 weeks following treatment with doxorubicin (DOX) and $\mathrm{CaO}_{2}$-MNPs. The body weights of mice were determined and none of the treatment produced significant losses of body weight or any apparent abnormalities (Figure 6A). Furthermore, tumor growth was monitored weekly with an in vivo imaging system (IVIS) system and quantified via bioluminescence imaging (Figure 6B). The results showed that tumor volume had a gradual increase in the control 
group. We found while DOX alone decreased primary growth of TNBC, $\mathrm{CaO}_{2}-\mathrm{MNPs}$ further enhanced TNBC response to DOX in vivo (Figure 6B). We also observed a significant reduction in tumor weight in mice received the combination treatment in comparison to those treated with DOX alone (Figure 6C). In addition, we performed histological staining of tumor sections with antibodies against HIF- $1 \alpha$ and LC3, the readouts of hypoxia and autophagy, respectively (Figure 6D). HIF- $1 \alpha$ expression in tumor tissue in the combination groups was lower than that in the control and DOX groups. Moreover, DOX in combination with $\mathrm{CaO}_{2}-\mathrm{MNP}$ further decreased $\mathrm{LC} 3$ expression compared to the DOX treatment alone. These results indicated that the combination of DOX and $\mathrm{CaO}_{2}-\mathrm{MNP}$ inhibited autophagy and hypoxia in vivo and thus suppressed tumor growth in an orthotopic TNBC model.


Figure 6. The anti-cancer effects of DOX in combination with $\mathrm{CaO}_{2}-\mathrm{MNPs}$ in an orthotopic mouse model. The female Balb/c mice were injected with $5 \times 10^{4} 4 \mathrm{~T} 1$ cells orthotopically into the 4 th mammary fat pad. (A) the body weight was measured weekly in the different groups. (B) the bioluminescence imaging of tumors was used in vivo imaging system (IVIS) 200 system with Living Image Software. (C) the tumor weight was analyzed after sacrificing. ${ }^{*} p<0.05$ control compared with $\mathrm{DOX}+\mathrm{CaO}_{2}$-MNPs. (D) specific immunostaining was conducted on $4 \mathrm{~T} 1$ tumor sections showing the expression of HIF- $1 \alpha$ and LC3 in response to various treatments in vivo. Scale bars $=50 \mu \mathrm{m}$. 


\section{Discussion}

Accumulating evidence has reported that many advanced solid tumors may display anoxic and/or hypoxic tissue areas that are heterogeneously distributed within the tumor mass. The oxygenation level in several cancers including breast cancer is found to be lower than that in the respective normal tissues [11]. In the present study, the results from GSEA uncovered that the hypoxia gene set was significantly enriched in TNBC tissues (Figure 1A). When a tumor is growing, some regions of tumors undergo a decrease in $\mathrm{O}_{2}$, growth factors and glucose due to the poor vascularization of these regions [36,37]. Hypoxia increases HIF- $1 \alpha$ expression and the mechanisms by HIF- $1 \alpha$ target genes led to poorer patient survival through decreasing apoptosis, enhancing cancer cell survival and induction of angiogenesis [11]. Previous research has shown that the Bcl-2 family anti-apoptotic member Mcl-1 was overexpressed by hypoxia in human polymorphonuclear leukocytes [38]. Hypoxia can also protect cells against apoptotic cell death induced by anti-cancer drugs (taxol and fluorouracil) in pheochromocytoma cells [39]. In this study, we showed the evidence that chemical hypoxia $\left(\mathrm{CoCl}_{2}\right)$ stabilized HIF-1 $\alpha$ protein (Figure 2A) and reduced cell death induced by doxorubicin in $4 \mathrm{~T} 1$ cells (Figure 2B). Furthermore, hypoxia inhibited doxorubicin-induced apoptosis and the expression of apoptosis-associated proteins (Figure 3).

$\mathrm{CaO}_{2}-\mathrm{MNPs}$ were successfully prepared and mainly confirmed by increased hydrodynamic diameters (Figure S1A) and obvious changes of surface charges (Figure 1B). The obvious change in surface charges from $-30.6 \mathrm{mV}$ (from COOH-MNPs) to $-9.3 \mathrm{mV}$ due to $\mathrm{Ca}^{2+}$ adsorbed the $\mathrm{COO}^{-}$groups on the particle surface to form $\mathrm{Ca}^{2+} / \mathrm{COOH}-\mathrm{MNPs}$ (Figure S1B). The increased hydrodynamic diameter from $32.5 \mathrm{~nm}$ to $45.1 \mathrm{~nm}$ also confirmed the successful synthesis of $\mathrm{CaO}_{2}$-MNPs from COOH-MNPs. TEM images showed $\mathrm{CaO}_{2}-\mathrm{MNPs}$ were slightly aggregated (Figure $4 \mathrm{~A}$ ). Actually, $\mathrm{CaO}_{2}-\mathrm{MNPs}$ showed the welldispersion and no aggregation in water because of its hydrodynamic diameter was $45.1 \mathrm{~nm}$ (Figure S1B). To evaluate the oxygen release function of $\mathrm{CaO}_{2}-\mathrm{MNPs}, \mathrm{CaO}_{2}-\mathrm{MNPs}$ and $\mathrm{Ca}^{2+} / \mathrm{COOH}-\mathrm{MNPs}$ were mixed with deoxygenated water at room temperature. The obvious increased $\mathrm{DO}$ values were observed in $\mathrm{CaO}_{2}-\mathrm{MNPs}$ and the elevating DO levels was $3.5 \mathrm{mg} / \mathrm{L}$ (Figure 4B). These results proved that oxygen was certainly generated from $\mathrm{CaO}_{2}-$ MNPs. Notably, the bubbles were only found when $\mathrm{CaO}_{2}-\mathrm{MNPs}$ incubated with water for $10 \mathrm{~min}$ (Figure $4 \mathrm{C}$ ). No bubbles could not be observed when $\mathrm{Ca}^{2+} / \mathrm{COOH}-\mathrm{MNPs}$ incubated with water, even the incubation time prolonged to $2 \mathrm{~h}$. To further evaluate the safety of $\mathrm{CaO}_{2}-\mathrm{MNPs}$ for further cellular and animal experiments, the $\mathrm{pH}$ values were monitored after $\mathrm{CaO}_{2}$-MNPs incubated with PBS buffer ( $\mathrm{pH}$ 7.4) and deionized water (Figure 4D). Because the side products after $\mathrm{CaO}_{2}-\mathrm{MNPs}$ mixed with water were $\mathrm{Ca}(\mathrm{OH})_{2}$ and water. $\mathrm{Ca}(\mathrm{OH})_{2}$ could produce $\mathrm{OH}^{-}$to increase $\mathrm{pH}$ value in water. As seen as Figure $4 \mathrm{D}$, the $\mathrm{pH}$ values slightly increased from 7.0 to 7.8 when $\mathrm{CaO}_{2}-\mathrm{MNPs}$ mixed with deionized water for about $5 \mathrm{~h}$, but the $\mathrm{pH}$ values kept about 7.4 when $\mathrm{CaO}_{2}$-MNPs mixed with PBS buffer ( $\mathrm{pH}$ 7.4). This means $\mathrm{CaO}_{2}$-MNPs will not affect or change the $\mathrm{pH}$ value in physiological system after they are injected into body. Notably, when $\mathrm{Ca}^{2+} / \mathrm{COOH}-\mathrm{MNPs}$ incubated with deionized water, the $\mathrm{pH}$ values also had no changes. These results confirmed that $\mathrm{CaO}_{2}-\mathrm{MNPs}$ could generate oxygen again.

Ample evidence has indicated that the poor vascular blood and flow oxygen availability in hypoxic tumor tissues caused insufficient drug delivery [40]. Currently, nanocarriers has great potential to specifically enhance drug accumulation in hypoxic tumor cells due to enhanced permeability and retention (EPR) effect [41]. Previously the authors reported that nanoparticles co-loading oxygen and erlotinib reversed hypoxia-induced drug resistance in lung cancer. This drug and oxygen co-delivery strategy downregulated the expression of the protein p-EGFR, EGFR and HIF- $1 \alpha$, markedly suppressed cell proliferation and triggered apoptosis [28]. Another study concluded that the oxygen-delivery microbubbles decreased the hypoxia of pancreatic cancer cells and ameliorated sonodynamic therapeutic effect [26]. In the current study, we used $\mathrm{CaO}_{2}-\mathrm{MNPs}$ to release oxygen and found that $\mathrm{CaO}_{2}-\mathrm{MNPs}$ can degrade the $\mathrm{CoCl}_{2}$-stabilized HIF-1 $\alpha$ protein in TNBC cells (Figure 5A). Moreover, $\mathrm{CaO}_{2}$-MNPs decreased the HIF- $1 \alpha$ expression in tumor tis- 
sues of TNBC (Figure 6D). Oxygen by $\mathrm{CaO}_{2}-\mathrm{MNPs}$ can induce HIF-1 $\alpha$ ubiquitination and cause HIF-1 $\alpha$ degradation (Figure 5B). However, more precise molecular mechanism of HIF-1 $\alpha$ ubiquitination by oxygen should be investigated in the future. In addition, $\mathrm{CaO}_{2}$-MNPs inhibited the $\mathrm{CoCl}_{2}$-induced doxorubicin-resistance (Figure $5 \mathrm{C}$ ) but promoted the doxorubicin-induced apoptosis under $\mathrm{CoCl}_{2}$ treatment (Figure 5E). Moreover, an orthotopic TNBC mouse model showed a significantly decreased tumor weight in mice with the combination treatment $\left(\mathrm{CaO}_{2}-\mathrm{MNPs}+\mathrm{DOX}\right)$ compared to those treated with DOX alone (Figure $6 \mathrm{C}$ ). Therefore, the combination of DOX and $\mathrm{CaO}_{2}-\mathrm{MNPs}$ decreases HIF- $1 \alpha$ protein expression in vivo and, thus, attenuates hypoxia responses to inhibit tumor growth in TNBC.

Our results found that the autophagy gene set was remarkably enriched in TNBC patients (Figure 1B). In our in vitro study, chemical hypoxia $\left(\mathrm{CoCl}_{2}\right)$ itself did not trigger autophagy. However, upon DOX treatment in hypoxic condition TNBC cells did appear to activate autophagy. Furthermore, cells pre-treated with $\mathrm{CoCl}_{2}$ induced higher percentage of autophagic cells than that with DOX treatment alone; moreover, this phenotype was, accompanied with upregulation of the autophagy-related proteins p62 and LC3-II (Figure 3C,D). The in vitro and in vivo findings collectively evidenced that combining DOX with $\mathrm{CaO}_{2}-\mathrm{MNP}$ significantly suppressed autophagic effect compared to the DOX treatment alone (Figures 5D and 6D). These observations are consistent with previous reports. In a study conducted in the human TNBC cell line MDA-MB-231, taxol treatment under hypoxic condition activated cytoprotective autophagy through inhibition of the mTOR pathway but hypoxia itself did not induce autophagy. The resistance against taxol-induced cell death under hypoxia can be explained by autophagic process [23]. Wu et al. indicated that autophagy inhibition effectively increased cisplatin-induced apoptosis, suggesting the involvement of autophagy in cisplatin resistance under hypoxia in lung cancer cells [42]. Many studies concluded that autophagy reduces the sensitivity to cancer therapy $[20,43]$. One key mechanism underlying radiotherapy and chemotherapy-induced resistance is the AMPK pathway, which both activate ULK1 and inhibit mTOR signaling to trigger autophagy [44]. AMPK-ULK1 pathway were found to have a cytoprotective mechanism against chemotherapy in pancreatic cancer cells [45]. Accumulating evidence indicates that many types of cancer cells can activate autophagy to confer resistance to different chemotherapies.

The limitation of the study is the process of oxygen generation of $\mathrm{CaO}_{2}-\mathrm{MNPs}$. Because the mechanism of oxygen release is due to $\mathrm{CaO}_{2}$ reacts with water. It means that $\mathrm{CaO}_{2}-\mathrm{MNPs}$ can immediately generate oxygen when environment has water. In this study, this limitation was very small because $\mathrm{CaO}_{2}-\mathrm{MNPs}$ were injected into mice by intratumorally injection. In future studies, $\mathrm{CaO}_{2}-\mathrm{MNPs}$ will be designed to inject into mice by tail vein injection. Before $\mathrm{CaO}_{2}-\mathrm{MNPs}$ accumulate in tumor region, the oxygen release of $\mathrm{CaO}_{2}-\mathrm{MNPs}$ is continuous. So, the real oxygen amount in tumor region will be less than theoretical value and hard to be estimated. Although this problem can be overcome by increase dosage of $\mathrm{CaO}_{2}$-MNPs, the safety drug dosage needs to be concerned if drug-loaded $\mathrm{CaO}_{2}-\mathrm{MNPs}$ are used. The excess drugs may cause side effects. The other limitation of the study is moisture content in tumor region. Unfortunately, the moisture contents in tumor microenvironment are different and hard to estimated. Using the same dosage of $\mathrm{CaO}_{2}$-MNPs may generate different amount of oxygen, even the tumor sizes are the same. Therefore, the therapeutic efficiency may have a little difference in experimental results with the same conditions. Importantly, the difference did not affect the proof-of concept that the oxygen release of $\mathrm{CaO}_{2}-\mathrm{MNPs}$ could certainly improve oxygen level in tumor region and then reduce the drug resistance of cancer cells to get more therapeutic efficiency.

\section{Materials and Methods}

\subsection{Preparation of COOH-Modified MNPs (COOH-MNPs)}

To synthesize COOH-MNPs, the $\mathrm{NH}_{2}-\mathrm{MNPs}$ [46] were used as a starting material. First, $1 \mathrm{~mL}$ of succinic acid (45 mM), $45 \mu \mathrm{mol}$ of 1-ethyl-3-(3-dimethylaminopropyl)carbod- 
iimide (EDC) and $9 \mathrm{~mL}$ of $\mathrm{NH}_{2}$-MNPs (Fe concentration: $2 \mathrm{mg} / \mathrm{mL}$ ) were mixed for $10 \mathrm{~min}$. Following, the mixture solution stirred for $2 \mathrm{~h}$. Acetone was added the solution to produce precipitates and then precipitates were collected by centrifuged at $6000 \mathrm{rpm}$ for $15 \mathrm{~min}$. The supernatant was discarded, and then deionized water was added to disperse the precipitates (COOH-MNPs) for further use.

\subsection{Preparation of $\mathrm{CaO}_{2}-$ Modified $M N P S\left(\mathrm{CaO}_{2}-\mathrm{MNPs}\right)$}

The preparation of $\mathrm{CaO}_{2}$ referred as described by Khodaveisi et al. [47] with slight modification. First, $1 \mathrm{~mL}$ of $\mathrm{CaCl}_{2}$ aqueous solution $(0.01 \mathrm{M})$ was added into the aqueous solution of $\mathrm{COOH}-\mathrm{MNPs}$ and then using a permanent magnet to isolate the precipitates ( $\left.\mathrm{Ca}^{2+} / \mathrm{COOH}-\mathrm{MNPs}\right)$. Following, polyethylene glycol (M.W. 200) (PEG200) was added to dissolve the precipitates and the mixtures were sonicated until the precipitates fully dispersed in PEG200. Finally, $2 \mathrm{~mL}$ of $30 \%(w / w) \mathrm{H}_{2} \mathrm{O}_{2}$ was slowly added into PEG solution. The mixtures were gently stirred at room temperature for $0.5 \mathrm{~h}$ and then centrifuged at $6000 \mathrm{rpm}$ to remove PEG solution. Acetone was used to wash the precipitates twice and then PEG200 was added to redisperse the precipitate $\left(\mathrm{CaO}_{2}-\mathrm{MNPs}\right)$ for further experiments. The Fe ion concentration for the $\mathrm{CaO}_{2}-\mathrm{MNPs}$ was determined by an atomic absorption (AA) analysis.

\subsection{Characterization of $\mathrm{CaO}_{2}-\mathrm{MNPS}$}

The preparation of $\mathrm{CaO}_{2}$ referred as described by Khodaveisi et al. [47] with slight modification. First, $1 \mathrm{~mL}$ of $\mathrm{CaCl}_{2}$ aqueous solution $(0.01 \mathrm{M})$ was added into the aqueous solution of $\mathrm{COOH}-\mathrm{MNPs}$ and then using a permanent magnet to isolate the precipitates $\left(\mathrm{Ca}^{2+} / \mathrm{COOH}-\mathrm{MNPs}\right)$. Following, PEG200 was added to dissolve the precipitates and the mixtures were sonicated until the precipitates fully dispersed in PEG200. Finally, $2 \mathrm{~mL}$ of $30 \%(w / w) \mathrm{H}_{2} \mathrm{O}_{2}$ was slowly added into PEG solution. The mixtures were gently stirred at room temperature for $0.5 \mathrm{~h}$ and then centrifuged at $6000 \mathrm{rpm}$ to remove PEG solution. Acetone was used to wash the precipitates twice and then PEG200 was added to redisperse the precipitate $\left(\mathrm{CaO}_{2}-\mathrm{MNPs}\right)$ for further experiments. The Fe ion concentration for the $\mathrm{CaO}_{2}-\mathrm{MNPs}$ was determined by an AA analysis.

\subsection{Dissolved Oxygen (DO) Kinetics of $\mathrm{CaO}_{2}-\mathrm{MNPS}_{\mathrm{S}}$}

A measurement method was built by covering a beaker with a form cap. Two holes were cut into the foam cap in order to insert a DO meter and a glass pipette for nitrogen purging. Before the start of each experiments, $20 \mathrm{~mL}$ of deionized water was added to the beaker at room temperature, a DO meter was inserted into and purged with nitrogen to remove DO. Then, $1 \mathrm{~mL}$ of materials $\left(\mathrm{CaO}_{2}-\mathrm{MNPs}\right.$ and $\left.\mathrm{Ca}^{2+} / \mathrm{COOH}-\mathrm{MNPs}\right)$ at $0.9 \mathrm{mg} / \mathrm{mL}$ (Fe concentration) was injected into the closed system and then the DO values were monitored by a DO meter.

\subsection{Measuring $p H$ Values in Aqueous Solution of $\mathrm{CaO}_{2}-\mathrm{MNPS}$}

First, $20 \mathrm{~mL}$ of deionized water or PBS buffer ( $\mathrm{pH} 7.4$ ) was added to the beaker at room temperature and then a $\mathrm{pH}$ meter was inserted into this beaker. Following, $1 \mathrm{~mL}$ of $\mathrm{CaO}_{2}-\mathrm{MNPs}$ (or $\mathrm{Ca}^{2+} / \mathrm{COOH}-\mathrm{MNPs}$ ) at $0.9 \mathrm{mg} / \mathrm{mL}$ (Fe concentration) was injected into beaker and then the $\mathrm{pH}$ values were monitored by a $\mathrm{pH}$ meter.

\subsection{Gene Set Enrichment Analysis (GSEA)}

Microarray data were obtained from the Gene Expression Omnibus (GEO) GSE61725 data set. The gene lists of Harris or GO gene signature were obtained from the Molecular Signatures Database (MSigDB) [48].

\subsection{Cell Culture}

The human breast cancer cell line MDA-MB-231 (ATCC HTB-26) and murine breast cancer cell line 4T1 (ATCC CRL-2539) were purchased from the American Type Culture 
Collection (ATCC) (Manassas, VA, USA). The luciferase-expressing 4T1-Luc was acquired from Professor Yi-Ching Wang (Department of Pharmacology, National Cheng Kung University, Tainan, Taiwan). The cells were incubated in Dulbecco's modified essential medium (DMEM) (Gibco BRL, Grand Island, NY, USA) with $100 \mathrm{U} / \mathrm{mL}$ of penicillin, $100 \mu \mathrm{g} / \mathrm{mL}$ of streptomycin (Gibco BRL) and 10\% fetal bovine serum (Caisson Labs, Logan, UT, USA). The cells were cultured at $37^{\circ} \mathrm{C}$ in a humidified atmosphere containing $5 \% \mathrm{CO}_{2}$.

\subsection{Cell Viability}

Cells were collected and resuspended in phosphate-buffered saline. Each cell suspension and an equal amount of trypan blue solution was mixed. Then, the mixture was added on a hemocytometer. Alive cells were shown as no trypan blue-stained cells.

\subsection{Determination of Apoptosis}

An Annexin V apoptosis detection kit (Calbiochem, San Diego, CA, USA) was used to assess the phosphatidyl serine translocated to the cell surface. Cells were harvested and were added to Annexin V-FITC. Then, the labeled cells were quantified by flow cytometry (BD Biosciences, San Jose, CA, USA).

\subsection{Determination of Autophagy}

Cell staining with acridine orange (Sigma-Aldrich, St. Louis, MO, USA) was analyzed for detection of acidic vesicular organelles, which is a characteristic of autophagy. Cells were collected and stained with $1 \mu \mathrm{g} / \mathrm{mL}$ AO for $20 \mathrm{~min}$. Then, cells were quantified using flow cytometry (BD Biosciences).

\subsection{Western Blot Analysis and Immunoprecipitation (IP)}

Cells were lysed in lysis buffer at $4{ }^{\circ} \mathrm{C}$ for $1 \mathrm{~h}$. Proteins, which were isolated from the cells were loaded and separated by SDS-PAGE. The gels were transferred to polyvinylidene fluoride membranes and the membranes were then blocked with skim milk. The membranes were incubated with primary antibody at $4{ }^{\circ} \mathrm{C}$ overnight. An anti-HIF- $1 \alpha$ antibody was obtained from Novus Biologicals (Littleton, CO, USA); anti-ubiquitin antibody was obtained from BioLegend Inc. (San Diego, CA, USA); anti-GAPDH, anti-LC3, anti-Bax and anti-Bcl-XL antibodies were obtained from Cell Signaling Technology (Ipswich, MA, USA); active + pro caspase-3 antibody was obtained from ABclonal Inc. (Boston, MA, USA); and an anti-p62/SQSTM1 antibody was obtained from MBL (Nagoya, Japan). After washing three times, the membranes were incubated with horseradish peroxidase (HRP)-conjugated secondary antibody for $1 \mathrm{~h}$. Finally, the signals of membranes were examined by immobilon Western Chemiluminescent HRP Substrate (Merck Millipore, Darmstadt, Germany) and exposed to X-ray film.

For IP analysis, whole-cell protein lysates were added with anti-HIF- $1 \alpha$ antibody overnight at $4{ }^{\circ} \mathrm{C}$ and then were added with protein G plus/protein agarose (Merck Millipore, Darmstadt, Germany) for $1 \mathrm{~h}$. After washing, the beads were resuspended and boiled for $10 \mathrm{~min}$ at $95^{\circ} \mathrm{C}$. The supernatant was used to western blot analysis as described above. Raw data of Western blot is shown in Figure S2.

\subsection{In Vivo Orthotopic Breast Cancer Model}

Six-week-old female Balb/c mice were obtained from the National Laboratory Animal Center (Taiwan) and housed with $60 \% \pm 5 \%$ relative humidity at $23 \pm 2{ }^{\circ} \mathrm{C}$ in the Laboratory Animal Center, College of Medicine, National Cheng Kung University. The animal experiment was approved by the Institutional Animal Care and Use Committee of National Cheng Kung University (IACUC Approval Number: 107247). 4T1-Luc cells $\left(5 \times 10^{4}\right.$ cells) were injected into the 4 th of mammary fat pads in mice for one week. Then, the mice were randomized into four groups ( $n=5$ for each group): (1) the control, which was intraperitoneally (i.p.) injected with DMSO, (2) the DOX group: Which was i.p. injected with $3 \mathrm{mg} / \mathrm{kg}$ doxorubicin once per week for three weeks, (3) the DOX $+2 \mathrm{mg} / \mathrm{kg}$ 
$\mathrm{CaO}_{2}-\mathrm{MNPs}$ group, which was i.p. injected with $3 \mathrm{mg} / \mathrm{kg}$ doxorubicin once per week and intratumorally injected $2 \mathrm{mg} / \mathrm{kg} \mathrm{CaO}_{2}$-MNPs two times per week for three weeks and (4) the $\mathrm{DOX}+4 \mathrm{mg} / \mathrm{kg} \mathrm{CaO}_{2}-\mathrm{MNPs}$ group, which was i.p. injected with $3 \mathrm{mg} / \mathrm{kg}$ doxorubicin once per week and intratumorally injected $4 \mathrm{mg} / \mathrm{kg} \mathrm{CaO}_{2}-\mathrm{MNPs}$ two times per week for three weeks. Mouse body weight was examined once per week. Before imaging, mice were injected with VivoGlo Luciferin $(150 \mathrm{mg} / \mathrm{kg}$ ) (Promega, Madison, WI, USA) and anesthetized with isoflurane. The bioluminescence signal of tumors was used IVIS 200 system with Living Image Software (Xenogen, Alameda, CA, USA). Mice were sacrificed via $\mathrm{CO}_{2}$ and tumor tissues were collected and soaked by formalin.

\subsection{Immunohistochemical (IHC) Staining Analysis}

After soaking by formalin and embedding paraffin, tumor sections were deparaffinized in xylene and rehydrated by graded concentrations of ethanol in water. Then, microwave treatment in sodium citrate retrieved antigens. The tumor sections were immersed in $3 \% \mathrm{H}_{2} \mathrm{O}_{2} /$ methanol for $10 \mathrm{~min}$ to inhibit the activity of endogenous peroxidase. After washing, the slides were added with anti-HIF- $1 \alpha$ (Novus Biologicals, Littleton, CO, USA) and anti-LC3 (MBL, Nagoya, Japan) antibodies and used a Starr Trek Universal HRP detection kit (Biocare Medical, Concord, CA, USA) to detect the antibodies. Finally, the slides were stained with hematoxylin and coverslipped.

\subsection{Statistical Analysis}

All data are shown as the mean \pm standard deviation (SD) of the results from three independent experiments. The statistics of results was used with one-way analysis of variance followed by post hoc Dunnett's test or two-sample $t$-test. $p$ values $<0.05(p<0.05)$ in all analyses were considered statistical significance.

\section{Conclusions}

The hypoxia and autophagy gene sets were significantly enriched in TNBC patients, suggesting hypoxia and autophagy play a critical role in TNBC. Furthermore, we showed that DOX induced apoptosis and autophagy activation in TNBC cells. $\mathrm{CoCl}_{2}$ increased the resistance of TNBC cells to DOX. Additionally, hypoxia inhibited the induced apoptosis and increased autophagy by DOX. $\mathrm{CaO}_{2}$-MNPs can release oxygen and degrade HIF- $1 \alpha$ protein by ubiquitination. Moreover, $\mathrm{CaO}_{2}-\mathrm{MNPs}$ promoted cell death against DOXinduced resistance under hypoxia likely through the inhibition of autophagy and induction of apoptosis (Figure 7). In vivo, we found $\mathrm{CaO}_{2}-\mathrm{MNPs}$ further decrease tumor growth and tumor weight under DOX treatment. The in vitro and in vivo findings indicated that the co-treatment of $\mathrm{CaO}_{2}$-MNPs and DOX could be an effective approach to diminish HIF1 $\alpha$-mediated hypoxic response to modulate tumor growth of TNBC. 


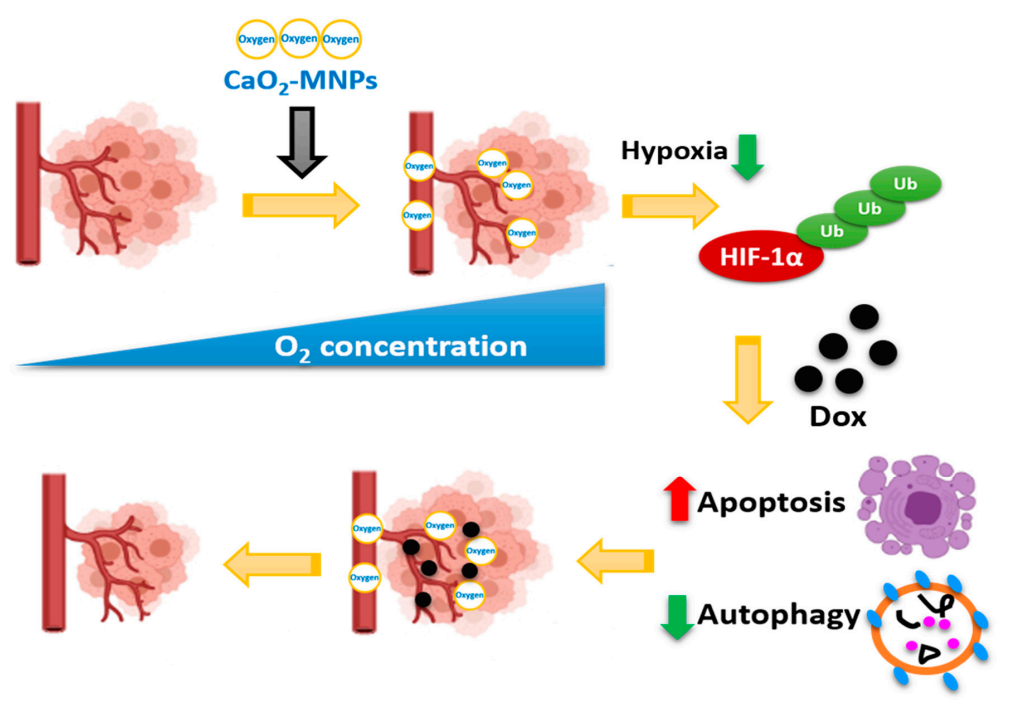

Figure 7. $\mathrm{CaO}_{2}-\mathrm{MNPs}$ attenuate hypoxia-induced chemoresistance in $\mathrm{TNBC}$. $\mathrm{CaO}_{2}-\mathrm{MNPs}$ release oxygen and degrade HIF-1 $\alpha$ protein by ubiquitination. Hypoxia inhibit the DOX-induced apoptosis and DOX-increased autophagy in TNBC cells. $\mathrm{CaO}_{2}-\mathrm{MNPs}$ promote cell death against DOXinduced resistance under hypoxia through the inhibition of autophagy and induction of apoptosis. Therefore, co-treatment with $\mathrm{CaO}_{2}-\mathrm{MNPs}$ and DOX could be an effective approach to attenuate HIF- $1 \alpha$-mediated hypoxic responses to modulate TNBC. The figure was created with BioRender.com.

Supplementary Materials: The following are available online at https: / /www.mdpi.com/2072-6 694/13/4/606/s1, Figure S1: Physical characteristics of COOH-MNPs and $\mathrm{CaO}_{2}-\mathrm{MNPs}$, Figure S2: Raw data of Western blot.

Author Contributions: Conceptualization, F.-Y.C., C.-H.C., Y.-J.W. and H.-W.C.; methodology, F.-Y.C., C.-H.C., B.-J.W. and Y.-L.Y.; investigation, Y.-J.W. and H.-W.C.; data curation, F.-Y.C., C.-H.C., B.-J.W. and Y.-L.Y.; writing—original draft preparation, F.-Y.C. and H.-W.C.; writing-review and editing, C.H.C. and Y.-J.W.; supervision, Y.-J.W. and H.-W.C. All authors have read and agreed to the published version of the manuscript.

Funding: This study was supported by the Ministry of Science and Technology, Taiwan (MOST 109-2314-B-038-078-MY3 and MOST 109-2314-B-006-051-MY3).

Institutional Review Board Statement: All animal experiments were reviewed and approved by the Institutional Animal Care and Use Committee of National Cheng Kung University (IACUC Approval Number: 107247) on 9 August 2018.

Informed Consent Statement: Not applicable.

Data Availability Statement: The data presented in this study are available in article or supplementary material.

Conflicts of Interest: The authors declare no conflict of interest.

\section{References}

1. Kumar, P.; Aggarwal, R. An overview of triple-negative breast cancer. Arch. Gynecol. Obstet. 2016, 293, 247-269. [CrossRef] [PubMed]

2. Shen, M.; Jiang, Y.Z.; Wei, Y.; Ell, B.; Sheng, X.; Esposito, M.; Kang, J.; Hang, X.; Zheng, H.; Rowicki, M.; et al. Tinagl1 suppresses triple-negative breast cancer progression and metastasis by simultaneously inhibiting integrin/FAK and EGFR signaling. Cancer Cell 2019, 35, 64-80. [CrossRef] [PubMed]

3. Cheng, X.; He, P.; Lee, T.; Yao, H.; Li, R.; Shen, Y. High activities of BACE1 in brains with mild cognitive impairment. Am. J. Pathol. 2014, 184, 141-147. [CrossRef] [PubMed]

4. Marotti, J.D.; de Abreu, F.B.; Wells, W.A.; Tsongalis, G.J. Triple-negative breast cancer: Next-Generation sequencing for target identification. Am. J. Pathol. 2017, 187, 2133-2138. [CrossRef]

5. Piret, J.P.; Cosse, J.P.; Ninane, N.; Raes, M.; Michiels, C. Hypoxia protects HepG2 cells against etoposide-induced apoptosis via a HIF-1-independent pathway. Exp. Cell. Res. 2006, 312, 2908-2920. [CrossRef] 
6. Xiong, H.; Nie, X.; Zou, Y.; Gong, C.; Li, Y.; Wu, H.; Qiu, H.; Yang, L.; Zhuang, L.; Zhang, P.; et al. Twist1 enhances hypoxia induced radioresistance in cervical cancer cells by promoting nuclear EGFR localization. J. Cancer 2017, 8, 345-353. [CrossRef]

7. Liverani, C.; De Vita, A.; Minardi, S.; Kang, Y.; Mercatali, L.; Amadori, D.; Bongiovanni, A.; La Manna, F.; Ibrahim, T.; Tasciotti, E. A biomimetic 3D model of hypoxia-driven cancer progression. Sci. Rep. 2019, 9, 12263. [CrossRef]

8. Chen, X.; Iliopoulos, D.; Zhang, Q.; Tang, Q.; Greenblatt, M.B.; Hatziapostolou, M.; Lim, E.; Tam, W.L.; Ni, M.; Chen, Y.; et al. XBP1 promotes triple-negative breast cancer by controlling the HIF1 $\alpha$ pathway. Nature 2014, 508, 103-107. [CrossRef]

9. Huang, M.; Chen, Q.; Xiao, J.; Yao, T.; Bian, L.; Liu, C.; Lin, Z. Overexpression of hypoxia-inducible factor-1 $\alpha$ is a predictor of poor prognosis in cervical cancer: A clinicopathologic study and a meta-analysis. Int. J. Gynecol. Cancer 2014, 24, 1054-1064. [CrossRef]

10. Yang, Y.; Yang, Y.; Yang, X.; Zhu, H.; Guo, Q.; Chen, X.; Zhang, H.; Cheng, H.; Sun, X. Autophagy and its function in radiosensitivity. Tumour Biol. 2015, 36, 4079-4087. [CrossRef]

11. Vaupel, P.; Mayer, A. Hypoxia in cancer: Significance and impact on clinical outcome. Cancer Metastasis Rev. 2007, 26, 225-239. [CrossRef] [PubMed]

12. Adams, J.M.; Difazio, L.T.; Rolandelli, R.H.; Luján, J.J.; Haskó, G.; Csóka, B.; Selmeczy, Z.; Németh, Z.H. HIF-1: A key mediator in hypoxia. Acta Physiologica Hungarica 2009, 96, 19-28. [CrossRef] [PubMed]

13. Liu, J.; Zhang, J.; Wang, X.; Li, Y.; Chen, Y.; Li, K.; Zhang, J.; Yao, L.; Guo, G. HIF-1 and NDRG2 contribute to hypoxia-induced radioresistance of cervical cancer Hela cells. Exp. Cell Res. 2010, 316, 1985-1993. [CrossRef] [PubMed]

14. Lin, S.C.; Liao, W.L.; Lee, J.C.; Tsai, S.J. Hypoxia-regulated gene network in drug resistance and cancer progression. Exp. Biol. Med. 2014, 239, 779-792. [CrossRef] [PubMed]

15. Comerford, K.M.; Wallace, T.J.; Karhausen, J.; Louis, N.A.; Montalto, M.C.; Colgan, S.P. Hypoxia-inducible factor-1-dependent regulation of the multidrug resistance (MDR1) gene. Cancer Res. 2002, 62, 3387-3394. [PubMed]

16. Comerford, K.M.; Cummins, E.P.; Taylor, C.T. c-Jun NH2-terminal kinase activation contributes to hypoxia-inducible factor 1alpha-dependent P-glycoprotein expression in hypoxia. Cancer Res. 2004, 64, 9057-9061. [CrossRef]

17. Liu, J.; Zhang, C.; Zhao, Y.; Yue, X.; Wu, H.; Huang, S.; Chen, J.; Tomsky, K.; Xie, H.; Khella, C.A.; et al. Parkin targets HIF-1 $\alpha$ for ubiquitination and degradation to inhibit breast tumor progression. Nat. Commun. 2017, 8, 1823. [CrossRef]

18. Wang, R.; Zhang, P.; Li, J.; Guan, H.; Shi, G. Ubiquitination is absolutely required for the degradation of hypoxia-inducible factor-1 alpha protein in hypoxic conditions. Biochem. Biophys. Res. Commun. 2016, 470, 117-122. [CrossRef]

19. White, E. The role for autophagy in cancer. J. Clin. Invest. 2015, 125, 42-46. [CrossRef]

20. Folkerts, H.; Hilgendorf, S.; Vellenga, E.; Bremer, E.; Wiersma, V.R. The multifaceted role of autophagy in cancer and the microenvironment. Med. Res. Rev. 2019, 39, 517-560. [CrossRef]

21. Cicchini, M.; Chakrabarti, R.; Kongara, S.; Price, S.; Nahar, R.; Lozy, F.; Zhong, H.; Vazquez, A.; Kang, Y.; Karantza, V. Autophagy regulator BECN1 suppresses mammary tumorigenesis driven by WNT1 activation and following parity. Autophagy 2014, 10, 2036-2052. [CrossRef] [PubMed]

22. Han, Y.; Fan, S.; Qin, T.; Yang, J.; Sun, Y.; Lu, Y.; Mao, J.; Li, L. Role of autophagy in breast cancer and breast cancer stem cells (review). Int. J. Oncol. 2018, 52, 1057-1070. [CrossRef] [PubMed]

23. Notte, A.; Ninane, N.; Arnould, T.; Michiels, C. Hypoxia counteracts taxol-induced apoptosis in MDA-MB-231 breast cancer cells: Role of autophagy and JNK activation. Cell Death Dis. 2013, 4, e638. [CrossRef] [PubMed]

24. Gao, Y.; Xie, J.; Chen, H.; Gu, S.; Zhao, R.; Shao, J.; Jia, L. Nanotechnology-based intelligent drug design for cancer metastasis treatment. Biotechnol. Adv. 2014, 32, 761-777. [CrossRef]

25. Estanqueiro, M.; Amaral, M.H.; Conceição, J.; Sousa Lobo, J.M. Nanotechnological carriers for cancer chemotherapy: The state of the art. Colloids Surf. B Biointerfaces 2015, 126, 631-648. [CrossRef]

26. McEwan, C.; Kamila, S.; Owen, J.; Nesbitt, H.; Callan, B.; Borden, M.; Nomikou, N.; Hamoudi, R.A.; Taylor, M.A.; Stride, E.; et al. Combined sonodynamic and antimetabolite therapy for the improved treatment of pancreatic cancer using oxygen loaded microbubbles as a delivery vehicle. Biomaterials 2016, 80, 20-32. [CrossRef]

27. McEwan, C.; Owen, J.; Stride, E.; Fowley, C.; Nesbitt, H.; Cochrane, D.; Coussios, C.C.; Borden, M.; Nomikou, N.; McHale, A.P.; et al. Oxygen carrying microbubbles for enhanced sonodynamic therapy of hypoxic tumours. J. Control. Release 2015, 203, 51-56. [CrossRef]

28. Li, F.; Mei, H.; Gao, Y.; Xie, X.; Nie, H.; Li, T.; Zhang, H.; Jia, L. Co-delivery of oxygen and erlotinib by aptamer-modified liposomal complexes to reverse hypoxia-induced drug resistance in lung cancer. Biomaterials 2017, 145, 56-71. [CrossRef]

29. Schmidtke, T.; White, D.; Woolard, C. Oxygen release kinetics from solid phase oxygen in Arctic Alaska. J. Hazard. Mater. 1999, 64, 157-165. [CrossRef]

30. Harrison, B.S.; Eberli, D.; Lee, S.J.; Atala, A.; Yoo, J.J. Oxygen producing biomaterials for tissue regeneration. Biomaterials 2007, 28, 4628-4634. [CrossRef]

31. Oh, S.H.; Ward, C.L.; Atala, A.; Yoo, J.J.; Harrison, B.S. Oxygen generating scaffolds for enhancing engineered tissue survival. Biomaterials 2009, 30, 757-762. [CrossRef] [PubMed]

32. Ho, V.T.; Bunn, H.F. Effects of transition metals on the expression of the erythropoietin gene: Further evidence that the oxygen sensor is a heme protein. Biochem. Biophys. Res. Commun. 1996, 223, 175-180. [CrossRef] [PubMed]

33. Wei, T.; Xiaojun, X.; Peilong, C. Magnoflorine improves sensitivity to doxorubicin (DOX) of breast cancer cells via inducing apoptosis and autophagy through AKT/mTOR and p38 signaling pathways. Biomed. Pharmacother. 2020, 121, 109139. [CrossRef] [PubMed] 
34. Paglin, S.; Hollister, T.; Delohery, T.; Hackett, N.; McMahill, M.; Sphicas, E.; Domingo, D.; Yahalom, J. A novel response of cancer cells to radiation involves autophagy and formation of acidic vesicles. Cancer Res. 2001, 61, 439-444. [PubMed]

35. Hochstrasser, M. Ubiquitin, proteasomes, and the regulation of intracellular protein degradation. Curr. Opin. Cell Biol. 1995, 7, 215-223. [CrossRef]

36. Tuszynski, G.P.; Sharma, M.R.; Rothman, V.L.; Sharma, M.C. Angiostatin binds to tyrosine kinase substrate annexin II through the lysine-binding domain in endothelial cells. Microvasc. Res. 2002, 64, 448-462. [CrossRef]

37. Parangi, S.; O’Reilly, M.; Christofori, G.; Holmgren, L.; Grosfeld, J.; Folkman, J.; Hanahan, D. Antiangiogenic therapy of transgenic mice impairs de novo tumor growth. Proc. Natl. Acad. Sci. USA 1996, 93, 2002-2007. [CrossRef]

38. Leuenroth, S.J.; Grutkoski, P.S.; Ayala, A.; Simms, H.H. The loss of Mcl-1 expression in human polymorphonuclear leukocytes promotes apoptosis. J. Leukoc. Biol. 2000, 68, 158-166.

39. Alvarez-Tejado, M.; Naranjo-Suarez, S.; Jiménez, C.; Carrera, A.C.; Landázuri, M.O.; del Peso, L. Hypoxia induces the activation of the phosphatidylinositol 3-kinase/Akt cell survival pathway in PC12 cells: Protective role in apoptosis. J. Biol. Chem. 2001, 276, 22368-22374. [CrossRef]

40. Shannon, A.M.; Bouchier-Hayes, D.J.; Condron, C.M.; Toomey, D. Tumour hypoxia, chemotherapeutic resistance and hypoxiarelated therapies. Cancer Treat. Rev. 2003, 29, 297-307. [CrossRef]

41. Peng, X.H.; Wang, Y.; Huang, D.; Wang, Y.; Shin, H.J.; Chen, Z.; Spewak, M.B.; Mao, H.; Wang, X.; Wang, Y.; et al. Targeted delivery of cisplatin to lung cancer using ScFvEGFR-heparin-cisplatin nanoparticles. ACS Nano 2011, 5, 9480-9493. [CrossRef] [PubMed]

42. Wu, H.M.; Jiang, Z.F.; Ding, P.S.; Shao, L.J.; Liu, R.Y. Hypoxia-induced autophagy mediates cisplatin resistance in lung cancer cells. Sci. Rep. 2015, 5, 12291. [CrossRef] [PubMed]

43. Qiu, S.; Sun, L.; Jin, Y.; An, Q.; Weng, C.; Zheng, J. Silencing of BAG3 promotes the sensitivity of ovarian cancer cells to cisplatin via inhibition of autophagy. Oncol. Rep. 2017, 38, 309-316. [CrossRef] [PubMed]

44. Li, H.; Chen, C. Inhibition of autophagy enhances synergistic effects of Salidroside and anti-tumor agents against colorectal cancer. BMC Complementary Altern. Med. 2017, 17, 538. [CrossRef]

45. Jang, J.E.; Eom, J.I.; Jeung, H.K.; Cheong, J.W.; Lee, J.Y.; Kim, J.S.; Min, Y.H. Targeting AMPK-ULK1-mediated autophagy for combating BET inhibitor resistance in acute myeloid leukemia stem cells. Autophagy 2017, 13, 761-762. [CrossRef]

46. Su, C.H.; Tsai, C.Y.; Tomanek, B.; Chen, W.Y.; Cheng, F.Y. Evaluation of blood-brain barrier-stealth nanocomposites for in situ glioblastoma theranostics applications. Nanoscale 2016, 8, 7866-7870. [CrossRef]

47. Khodaveisi, J.; Banejad, H.; Afkhami, A.; Olyaie, E.; Lashgari, S.; Dashti, R. Synthesis of calcium peroxide nanoparticles as an innovative reagent for in situ chemical oxidation. J. Hazard. Mater. 2011, 192, 1437-1440. [CrossRef]

48. Molecular Signatures Database (MSigDB). Available online: https://www.gsea-msigdb.org/gsea/msigdb (accessed on 29 January 2021). 